\title{
Teknik Pemberdayaan Keluarga Prasejahtera Melalui Optimalisasi Lahan Pekarangan Dengan Penanaman Pisang Cavendish
}

\author{
The DeVelopment TeChNiQues Of PRE-Welfare Families Through OPTIMIZATION OF \\ YARDS WITH PLANTED CAVENDISH BANANAS
${ }^{1}$ Yani Ramdani, ${ }^{2}$ Eti Kurniati, ${ }^{3}$ Icih Sukarsih, ${ }^{4}$ Gani Gunawan
${ }^{1,2,3,4}$ Program Studi Matematika FMIPA UNISBA
e-mail: ${ }^{1}$ yani_ramdani@ymail.com

\begin{abstract}
One of the government's efforts to alleviate the problem of poverty is explored community empowerment program. The biggest obstacle is faced Nagrog village in the enhancement of the welfare level is the lack of capital. They have the main potential are the farming and large yard. Community empowerment techniques were conducted: (1) Mapping of social conditions and to inventory the objective conditions of Nagrog village in it relation with the education level and community economic empowerment; (2) To Conduct training programs of Nagrog village communities through the optimization of yard area with the planting of Cavendish bananas; and (3) To identify the supporting factors and problems in the community to effort the assistance in the management of seed and Cavendish bananas.The education, occupation, and economic levels included in the category low. The enhancement of knowledge to optimize their yards in an effort to create jobs was done the counseling, planting seedlings of Cavendish bananas, and mentoring. Extension materials include: cultivation and Cavendish banana business opportunities, how to use seeds and Cavendish bananas, draft needs and possibilities KUBE formed. The factors and problems encountered in the postharvest banana growers and Cavendish are (1) Condition seedling growth; (2) Diseases; (3) post-harvest handling.
\end{abstract}

Keywords: empowerment techniques, counseling, mentoring, cavendish bananas

\begin{abstract}
Abstrak. Salah satu upaya pemerintah dalam mengentaskan masalah kemiskinan adalah digaungkannya program pemberdayaan masyarakat. Kendala utama yang dihadapi masyarakat desa Nagrog dalam meningkatkan tingkat kesejahteraan adalah keterbatasan modal. Potensi yang dimiliki adalah mata pencaharian utama bertani dan halaman pekarangan yang luas. Teknik pemberdayaan masyarakat yang dilakukan adalah: (1) Pemetaan kondisi sosial dan menginventarisasi kondisi objektif masyarakat desa Nagrog dalam kaitannya dengan kondisi pendidikan dan pemberdayaan ekonomi masyarakat; (2) Melakukan program pembinaan masyarakat desa Nagrog melalui optimalisasi lahan pekarangan dengan penanaman bibit pisang Cavendish; dan (3) Mengidentifikasi faktor pendukung dan permasalahan dalam upaya pendampingan masyarakat dalam pengelolaan bibit dan buah pisang Cavendish. Kondisi pendidikan, jenis pekerjaan, dan tingkat ekonomi termasuk dalam kategori rendah.Peningkatan pengetahuan untuk mengoptimalkan lahan pekarangan sebagai upaya menciptakan lapangan pekerjaan dilakukan melalui penyuluhan, penanaman bibit pisang Cavendish, dan pendampingan. Materi penyuluhan meliputi: budidaya dan peluang usaha pisang Cavendish, cara pemanfaatan bibit dan buah pisang Cavendish, membuat rancangan kebutuhan dan kemungkinan dibentuk KUBE. Faktor pendukung dan permasalahan yang dihadapi dalam penanam dan pasca panen pisang Cavendish adalah: (1) Kondisi pertumbuhan bibit; (2) Penyakit; (3) Penanganan pasca panen.
\end{abstract}

Kata Kunci: teknik pemberdayaan, penyuluhan, pendampingan, pisang Cavendish 


\section{Pendahuluan}

Program pemberdayaan masyarakat dapat dilakukan melalui pemanfaatan sumber daya alam (SDA) dan peningkatan sarana prasarana pedesaan. Hasil yang diharapkan adalah dapat mengembangkan pengetahuan, wawasan berpikir serta meningkatkan keterampilan dalam memecahkan problematika pendidikan, kesehatan, dan ekonomi masyarakat khususnya desa tertinggal. Program pemberdayaan masyarakat ini diharapkan dapat tercapai secara optimal melalui pemanfaatan sumber daya dan potensi ekonomi lokal yang ada demi terciptanya transformasi sosial masyarakat pedesaan. Potensi dalam diri dan lingkungan masyarakat dapat dijadikan modal yang akan direalisasikan secara bertahap dan berkesinambungan.

\section{Teknik Pemberdayaan}

Teknik-teknik pemberdayaan masyarakat di desa Nagrog dilakukan melalui: (1) Pemetaan kondisi sosial dan menginventarisasi kondisi objektif masyarakat desa dalam kaitannya dengan kondisi pendidikan dan pemberdayaan ekonomi masyarakat yang masih rendah sehingga perlu ditingkatkan; (2) Melakukan program pembinaan masyarakat desa dalam menanggulangi permasalahan sosial dan ekonomi melalui optimalisasi lahan pekarangan dengan penanaman bibit pisang Cavendish; dan (3) Mengidentifikasi faktor pendukung dan permasalahan dalam upaya pendampingan masyarakat dalam pengelolaan bibit dan buah pisang Cavendish.

Secara teknis dapat dijabarkan: (1) Sosialisasi program pembinaan masyarakat melalui perkenalan Tim, menjelaskan program dan tujuannya serta batas waktu pelaksanaan. Kondisi ini dilakukan untuk memberikan peluang bagi masyarakat, pemerintah desa, kecamatan, dan kabupaten untuk berpartisipasi secara aktif; (2) Kajian secara partisipatif untuk menentukan instrumen yang tepat untuk pemetaan kodisi pendidikan, ekonomi, dan upaya pembinaannya; (3) Dialog dan sharing hasil kajian secara partisipatif dengan aparat desa dan tokoh masyarakat dalam upaya mengintegrasikan rumusan dengan pengetahuan yang dimiliki masyarakat dan mengajak berpartisipasi dalam pelaksanaan program; (4) Menjaring aspirasi untuk menentukan prioritas program yang akan dilaksanakan sekaligus sebagai jawaban terhadap masalah yang dihadapi masyarakat sebagai pelaku utama program pembinaan dan mengacu pada pengoptimalanpotensi yang dimiliki; (5) Penyusunan renstra untuk menjamin keberlanjutan program pembinaan; (6) Pelaksanaan program dengan aturan dan mekanisme yang sudah disepakati. Dalam pelaksanaan program mungkin terjadi konflik yang dapat menurunkankan tingkat partisipasi masyarakat, maka perlu dibentuk badan mediasi konflik dan hindari bias kepentingan personal. Mediasi konflik dapat dilakukan dengan menggunakan pendekatan kultural, personal, hukum dan musyawarah untuk mencapai mufakat. (Subiyanto, 2014); (7) Monitoring dan evaluasi dilakukan untuk memandang keberhasilan program yang telah dilakukan, dan (8) Penyusunan laporan dan pendokumentasian.

\section{Hasil dan Pembahasan}

Penyebaran angket untuk mengetahui kondisi objektif masyarakat desa Nagrog dilakukan terhadap 200 kepala keluarga secara acak. Berikut adalah hasil analisis terhadap angket yang disebarkan. 


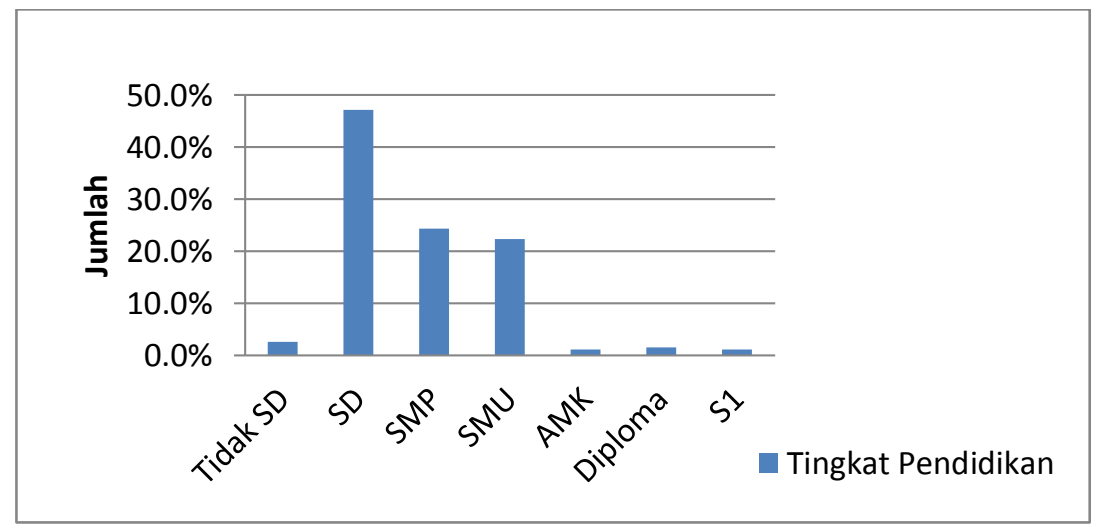

Tingkat pendidikan yang dimiliki warga desa Nagrog masih tergolong pada kategori rendah. Hal ini nampak jelas pada grafik di samping yaitu : 47,2 \% berpendidikan SD, 24,4 \% SMP, 22,3 \% SMU, 1 \% AMK, 1 \% Diploma, $1 \%$ S1 dan $2,6 \%$ tidak bersekolah.

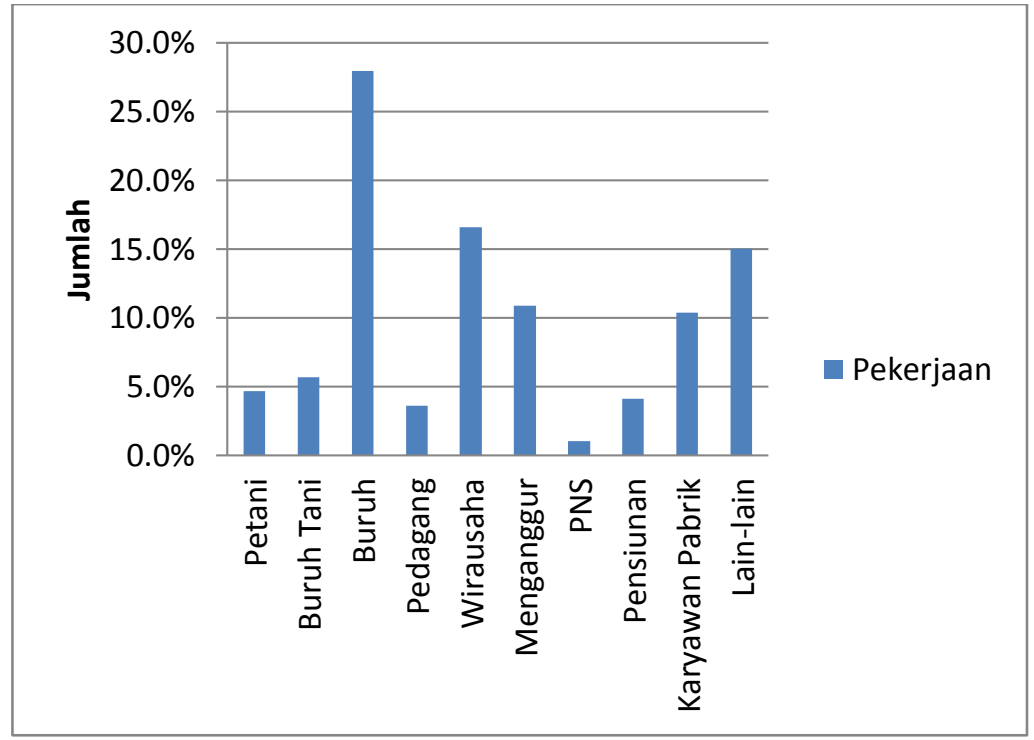

Jenis pekerjaan yang dilakukan warga desa Nagrog adalah 4,7 \% sebagai petani, $5,7 \%$ sebagai buruh tani, 28\% sebagai buruh, 3,6 \% sebagai pedagang, 16,6\% wirausaha, $10,9 \%$ tidak bekerja (menganggur), $1 \%$ sebagai PNS, $4,1 \%$ pensiunan, $10,4 \%$ karyawan pabrik dan $15 \%$ lainnya. Rincian tersebut dapat dilihat dalam grafik di samping. Jika dilihat dari warga desa Nagrog yang tidak memiliki pekerjaan dan jenis pekerjaan lainnya berjumlah $25,9 \%$. Jumlah ini cukup memprihatinkan. 


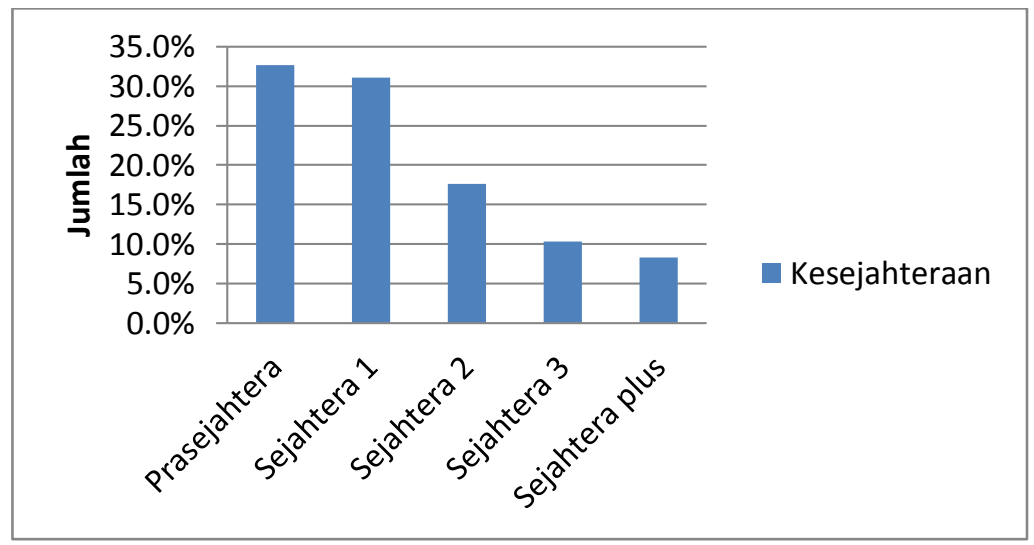

Tingkat kesejahteraan warga desa Nagrog dikelompokkan ke dalam 5 kelompok, yaitu: Prasejahtera, Sejahtera1, Sejahtera2,Sejahtera3, dan Sejahtera Plus. 32,6 \% penduduk desa Nagrog berada dalam keadaan prasejahtera, 31,1\% sejahtera1, 17,6 \% sejahtera 2,10,4\% sejahtera 3 dan $8,3 \%$ dalam keadaan sejahtera plus. Tingkat kesejahteraan penduduk desa Nagrog dapat dilihat dalam grafik di samping.

\section{Optimalisasi Lahan Pekarangan dengan Penanaman Bibit Pisang Cavendish}

Perkebunan pisang yang permanen (diusahakan terus menerus) dengan mudah dapat ditemukan di Meksiko, Jamaika, Amerika Tengah, Panama, Kolombia, Ekuador dan Filipina. Di negara tersebut, budidaya pisang sudah merupakan suatu industri yang didukung oleh kultur teknis yang prima dan stasiun pengepakan yang modern dan pengepakan yang memenuhi standard internasional. Hal tersebut menunjukkan bahwa pisang memang komoditas perdagangan yang sangat tidak mungkin diabaikan. Permintaan pisang dunia memang sangat besar terutama jenis pisang Cavendish yang meliputi $80 \%$ dari permintaan total dunia. Selain berpeluang dalam ekspor pisang utuh, saat ini ekspor pure pisang juga memberikan peluang yang baik. Pure pisang biasanya dibuat dari pisang cavendish dengan kadar gula 21-26\% atau dari pisang lainnya dengan kadar gula $<21 \%$.

Pisang memiliki memiliki manfaat: membantu tumbuh kembang janin; membantu tubuh menyimpan cadangan kalsium, nitrogen, dan fosfor untuk membangun perbaikan dan regenerasi jaringan; kaya akan mineral dan vitamin penting seperti vitamin $\mathrm{C}$ dan B kompleks, kalium, magnesium, fosfor, zat besi, kalsium; untuk mengobati sakit maag; masker untuk mengobati jerawat; dapat meningkatkan mood; menghaluskan kulit wajah; sebagai sumber energi; dapat digunakan untuk mengobati luka bakar; bermanfaat untuk mengalirkan oksigen ke otak; memperlancar metabolism; mengurangi rasa sakit pada saat haid; mengatasi gatal karena gigitan nyamuk; meningkatkan kekebalan tubuh, mengurangi hypertensi (darah tinggi); dan dapat digunakan untuk menurunkan berat badan.

Pisang Cavendish dikenal dengan sebutan Pisang Ambon Putih dikembangbiakan melalui metode kultur jaringan yang memiliki keunggulan dapat terbebas dari penyakit seperti layu moko akibat Pseudomonas solanacearum dan layu panama akibat Fusarium Oxysporum Cubense dibandingkan dengan pisang yang dikembangbiakan dengan cara anakan. Karakteristik yang dimiliki pisang Cavendish adalah tinggi batang sekitar 2,5 - 3 meter dengan warna hijau kehitaman, daun berwarna hijau tua, panjang tandan sekitar $60-100 \mathrm{~cm}$ dengan berat $15-30 \mathrm{~kg}$, setiap tandan berisi sekitar $8-13$ sisiran dan setiap sisiran berisi $12-22$ buah, warna daging putih kekuningan, rasanya manis agak asam dan lunak dengan kulit buah agak tebal berwarna hijau kekuningan sampai kuning muda halus. 
Di Indonesia pisang hanya ditanam dalam skala rumah tangga atau kebun yang sangat kecil. Standard internasional perkebunan pisang kecil adalah 10-30 ha. Angka ini belum dicapai di Indonesia. Tanah dan iklim Indonesia sangat mendukung penanaman pisang, karena itu secara teknis pendirian perkebunan pisang mungkin dilakukan. Komoditi pisang adalah salah satu komoditas unggulan pertanian yang sangat potensial untuk dikembangkan. Baik terkait dengan karakteristik teknis, sosial maupun ekonomis, dan dapat dibudidayakan di seluruh wilayah. Kebijakan, strategi dan program kegiatan pengembangan komoditi pisang disusun setelah memperhatikan berbagai aspek sehingga kebijakan, strategi dan program kegiatan yang dibuat nantinya dapat mencapai target yang telah ditetapkan.

Masyarakat desa Nagrog umumnya memiliki lahan pekarangan luas belum dimamfaatkan secara optimal. Salah satu upaya untuk meningkatkan tingkat kesehatan dan ekonomi adalah penanaman bibit pisang cavendihs di halaman pekarangan. Faktor pendukung agar bibit pisang Cavendish dapat tumbuh subur dan berbuah adalah kondisi alam memenuhi karakteristik: (1) Memiliki suhu antara $27^{\circ} \mathrm{C}-38^{0} \mathrm{C}$; (2) Curah hujan sekitar 200-220 mm; (3) Kelembaban tanah sekitar 60\% - 70\% dari kapasitas lapangan; dan (4) Kondisi tanah liat yang dalam dan gembur dengan toleransi $\mathrm{pH} 4,5-7,5$.

Peningkatan pengetahuan masyarakat desa Nagrog tentang cara pengoptimalan lahan pekarangan sebagai upaya menciptakan lapangan pekerjaan dilakukan melalui penyuluhan, penanaman bibit pisang Cavendish, dan pendampingan. Materi penyuluhan meliputi: budidaya dan peluang usaha pisang Cavendish, cara pemanfaatan bibit dan buah pisang Cavendish, membuat rancangan kebutuhan dan kemungkinan dibentuk kelompok usaha bersama (KUBE). Selanjutnya, melakukan kegiatan pertemuan forum tatap muka dengan perwakilan tokoh masyarakat desa secara rutin untuk keberlanjutan program.

Untuk mendapatkan kualitas buah yang baik dilakukan penyuluhan dengan materi pokok kegiatan pemeliharaan pisang Cavendish yaitu: (1) Pemangkasan daun kering bertujuan untuk mencegah penularan penyakit, mencegah daun-daun tua menutupi anakan dan melindungi buah dari goresan daun; (2) Penyiangan dan penggemburan tanah dengan selang waktu $2-3$ bulan; (3) Pembumbunan dilakukan jika umbi pisang muncul ke permukaan tanah dan pada saat beranak; (4) Pengairan dilakukan terutama di musim kemarau; (5) Penjarangan dilakukan rutin setiap $6-8$ minggu dengan memelihara 1 tanaman induk (umur 9 bulan), 1 anakan (umur 7 bulan) dan 1 anakan (umur 3 bulan); (6) Perawatan tandan dengan membersihkan daun sekitar tandan; dan (7) Sanitasi dilakukan 45 hari sekali meliputi kegiatan pembersihan daun kering, penjarangan anakan dan pembuangan sisa tanaman bekas panen.

Selain itu, penyuluhan dilakukan juga untuk meningkatkan pengetahuan masyarakat tentang cara pemanfaatan bibit dan buah pisang Cavendish untuk meningkatkan ekonomi kelurga. Materi penyuluhan ditekankan pada peluang usaha yang dapat dilakukan dengan materi perluasan wawasan wirausaha pisang Cavendish. Pisang Cavendish memilki karakter yang unik apabila dilihat dari cara pertumbuhan dan daya jual. Apabila di lihat dari nilai jual perbuah juga sangat pantastik yaitu berkisar Rp. 4000,00 sampai dengan 5000,00 perbuah. Karakter ini cocok untuk program pemberdayaan masyarakat mengingat kendala utama untuk memperbaiki kondisi ekonomi mereka adalah permodalan. Secara teoritis, pada saat panen akan menghasilkan minimal 96 buah atau sekitar Rp. 384.000 per pohon. Dalam peaksanaan program pemberdayaan satu kepala keluarga mendapatkan 5 buah bibit, ini berarti dalam jangka waktu 9 bulan pertama akan mendapat penghasilan sekitar 1.920.000,00. Lima bulan kemudian akan memperoleh penghasilan sekitar Rp. 2.840.000,00. Lima 
bulan kemudian akan memperoleh penghasilan sekitar Rp. 5.640.000,00, dan seterusnya. Perkiraan analisis budidaya pisang dengan luasan 1 ha di daerah Jawa Barat pada tahun 1999 nampak pada Tabel 1 sebagai berikut:

Tabel 1. Analisis Budidaya Pisang Cavendish

\begin{tabular}{|c|c|c|}
\hline $\begin{array}{l}\text { Biaya produksi } 1 \text { ha pisang dari } \\
\text { tahun ke- } 1 \text { sampai ke- } 4\end{array}$ & Penerimaan tahun ke I sampai IV & Keuntungan \\
\hline $\begin{array}{l}\text { 1. Tahun ke-1 Rp. 5.338.000,- } \\
\text { 2. Tahun ke-2 Rp. 4.235.000,- } \\
\text { 3. Tahun ke-3 Rp. 4.518.000,- } \\
\text { 4. Tahun ke-4 Rp. 4.545.300,-- }\end{array}$ & $\begin{array}{l}\text { 1. Tahun ke-1: } 0,8 \times 1.000 \text { tandan } \\
=\text { Rp. } 8.000 .000,- \\
\text { 2. Tahun ke-2: } 0,8 \times 2.000 \text { tandan } \\
=\text { Rp. } 16.000 .000,- \\
\text { 3. Tahun ke-3: } 0,8 \text { x } 2.000 \\
\text { tandan = Rp. } 16.000 .000,- \\
\text { 4. Tahun ke-4: } 0,8 \times 2.000 \text { tandan } \\
=\text { Rp. } 16.000 .000,-\end{array}$ & $\begin{array}{l}\text { Keuntungan selama } 4 \\
\text { tahun penanaman Rp. } \\
23.363 .700 \\
\text { Keuntungan/tahun Rp. } \\
\text { 5.840.925,- }\end{array}$ \\
\hline
\end{tabular}

Parameter Kelayakan Usaha Output/Input rasio $=2,150$ dengan perkiraan harga 1 tandan Rp. $10.000,-$.

\section{Faktor Pendukung dan Permasalahan}

Faktor perdukung dan permasalahan yang dihadapi masyarakat desa Nagrog dalam penanam dan pasca panen pisang Cavendish adalah: (1) Kondisi pertumbuhan: Suhu merupakan faktor utama untuk pertumbuhan tanaman Pisang Cavendish. Suhu optimum untuk pertumbuhannya adalah sekitar $27^{\circ} \mathrm{C}$, dan suhu maksimumnya $38^{\circ}$ C. Tanaman ini tumbuh di daerah tropis dan subtropis, pisang ini tidak dapat tumbuh di dataran tinggi, ketinggian di atas $1600 \mathrm{~m}$ dpl. Penanaman pisang di lahan terbuka yaitu halaman pekarangan dan lahan tidur. Kecepatan angin tidak terlalu kencang sehingga kondisi daunnya aman dari kemungkinan rusak dan robek, distorsi tajuk dan robohnya pohon. Curah hujan yang diperlukan cukup memadai sekitar 200-220 mm, dan kelembapan tanahnya tidak kurang dari 60-70\% dari kapasitas lapangan sehingga dapat tumbuh optimal. Tanah desa Nagrog cocok untuk pertumbuhan Pisang Cavendish karena pada umumnya merupakan tanah liat yang dalam dan gembur serta yang memiliki pengeringan danaerasi yang baik. Tanaman ini toleran terhadap $\mathrm{pH}$ 4,5-7,5; (2) Penyakit. Salah satu jenis penyakit yang kerap menyerang tanaman Pisang Cavendish adalah layu panama atau sering dikenal dengan nama layu fusarium. Penyakit ini membuat daun pisang menjadi layu dan mudah putus. Jamur penyebab penyakit ini adalah Fusarium oxysporum f.sp. cubense, yang mampu bertahan lama di dalam tanah sebagai klamidospora sehingga sulit untuk dikendalikan. Sejumlah cara pengendaliannya telah diteliti, namun belum memberikan hasil yang memuaskan. Contohnya adalah pengendalian hayati patogen yang ditularkan melalui tanah dan penggunaan jenis bakteri tertentu untuk mengendalikan patogen yang ditularkan melalui tanah tersebut. Selain layu panama, tanaman Pisang Cavendish juga dapat terkena penyakit Mycosphaerella Leaf Disease Complex (MLDC). Gejala-gejala yang ditimbulkan oleh penyakit ini adalah perkembangan tanaman yang buruk, daundaun menjadi layu dengan cepat, jumlah daun-daun yang sehat semakin berkurang, timbulnya tandan yang buruk, buah-buah yang dihasilkan tidak baik, dan perkembangan buahnya menjadi prematur. Sedangkan, contoh penyakit-penyakit lain dari Pisang Cavendish adalah Yellow Sigatoka yang disebabkan oleh M. musicola dan Black Leaf Streakatau Black Sigatoka yang disebabkan oleh M. fijiensis; dan (3) Pasca panen meliputi: perlakuan paska panen di lapangan masih sederhana, belum ada kebijakan 
penerapan pasca panen untuk mendorong/mewajibkan petani melakukan perlakuan pasca panen, memfasilitasi penerapan pasca panen pisang sesuai SOP (apresiasi \& pilot project), menggunakan panduan perlakuan pasca panen pisang.

\section{Kesimpulan}

Kondisi pendidikan, jenis pekerjaan, dan tingkat ekonomi warga desa Nagrog termasuk dalam kategori rendah. Teknik-teknik pemberdayaan masyarakat dilakukan melalui: (1) Pemetaan kondisi sosial dan menginventarisasi kondisi objektif masyarakat desa dalam kaitannya dengan kondisi pendidikan dan pemberdayaan ekonomi masyarakat yang masih rendah sehingga perlu ditingkatkan; (2) Mengidentifikasi permasalahan dalam upaya pembinaan masyarakat di bidang pendidikan (umum dan agama), yang dapat mengembangkan mutu kehidupan bermasyarakat; (3) Melakukan program pembinaan masyarakat desa dalam menanggulangi permasalahan sosial dan ekonomi melalui peningkatan kualitas dan kuantitas pisang Cavendish; (4) Melakukan pendidikan bagi Karang Taruna dan Kelompok Tani khususnya peningkatan pengetahuan tentang kewirausahaan pisang Cavendish; (5) membuat rancangan kebutuhan dan kemungkinan dibentuk kelompok usaha bersama (KUBE) sebagai upaya meningkatkan ekonomi kelurga dan menciptakan lapangan pekerjaan; dan (6) pengabdi melakukan kegiatan pertemuan forum tatap muka dengan perwakilan tokoh masyarakat desa secara rutin untuk keberlanjutan program.

Peningkatan pengetahuan masyarakat desa Nagrog tentang cara pengoptimalan lahan pekarangan sebagai upaya menciptakan lapangan pekerjaan dilakukan melalui penyuluhan, penanaman bibit pisang Cavendish, dan pendampingan. Faktor perdukung dan permasalahan yang dihadapi masyarakat desa Nagrog dalam penanam dan pasca panen pisang Cavendish adalah: (1) Kondisi pertumbuhan; (2) Penyakit.; dan (3) Pasca panen.

\section{Ucapan Terima Kasih}

\section{Daftar pustaka}

Anonim, Budidaya Pisang, (1980), Lembaga Penelitian Hortikultura Pasar Minggu Jakarta Indonesia.

Anonim, Teknologi Budidaya Pisang, (2008), B2P2TP Badan Penelitian dan Pengembangan Pertanian.

https://malikin90.wordpress.com/strategi-pemasaran-bagi-produk-baru/

https://miftakhulfirdaus.wordpress.com/2009/07/01/pengolahan-dan-pemasaran-hasilpisang/

http://peuyeumcipatat.blogspot.co.id/2013/05/cara-budidaya-pohon-pisang_3461.html http://bapemas.jatimprov.go.id/index.php/program/kegiatan-sda-ttg/307-program-

pemberdayaan-masyarakat-dalam-pemanfaatan-sumber-daya-alam-sda-dan-

peningkatan-sarana

http://www.kemsos.go.id/modules.php?name=Content\&pa=showpage\&pid=23 http://www.lemlit.uhamka.ac.id/index.php?pilih=news\&mod=yes\&aksi=lihat\&id=40\&j

udul=pemberdayaan-masyarakat-desa-tertinggal-melalui-pendekatan--pendidikan,ekonomi,-dan-lingkungan-.html 
http://bplhd.jakarta.go.id/slhd2012/Docs/Lap_SLHD/Lap_3C.htm

http://id.wikipedia.org/wiki/Pisang_Cavendish

http://inkesehatan.blogspot.com/2013/10/17-manfaat-buah-pisang-bagi-kesehatan.html

http://cybex.deptan.go.id/penyuluhan/pemeliharaan-tanaman-pisang

http://bp2sdmk.dephut.go.id/emagazine/

http://www.bantenhits.com/rumah-kata/opini/3280-program-pemberdayaan-masyarakatantara-solusi-dan-lahan-korupsi-1

Siti Hafsah Husas, PP Pusbangluh (2000) Budidaya Pisang, DEPTAN, Balai Pengkajian Teknologi Pertanian Palangkaraya.

Wayan Sukarya, 2013, Luaran KKN-PPM, Makalah Disampaikan Pada Workshop Kuliah Kerja Nyata (KKN) Pembelajaran Pemberdayaan Masyarakat (PPM), Bogor, 6-7 Desember 2013

Wisnu Nurcahyo, 2013, Operasional, Administrasi dan Pelaporan KKN-PPM, Disampaikan Pada Workshop Kuliah Kerja Nyata (KKN) Pembelajaran Pemberdayaan Masyarakat (PPM), Bogor, 6-7 Desember 2013. 